\title{
Understanding soil erosion impacts in temperate agroecosystems: bridging the gap between geomorphology and soil ecology using nematodes as a model organism
}

\author{
C. Baxter ${ }^{1,2}$, J. S. Rowan ${ }^{2}$, B. M. McKenzie ${ }^{1}$, and R. Neilson ${ }^{1}$ \\ ${ }^{1}$ The James Hutton Institute, Dundee, DD2 5DA, Scotland, UK \\ ${ }^{2}$ Centre for Environmental Change and Human Resilience, University of Dundee, Dundee, DD1 4HN, Scotland, UK \\ Correspondence to: C. Baxter (craig.baxter@hutton.ac.uk)
}

Received: 29 March 2013 - Published in Biogeosciences Discuss.: 30 April 2013

Revised: 23 August 2013 - Accepted: 15 September 2013 - Published: 10 November 2013

\begin{abstract}
.
Soil is a key asset of natural capital, providing a myriad of goods and ecosystem services that sustain life through regulating, supporting and provisioning roles, delivered by chemical, physical and biological processes. One of the greatest threats to soil is accelerated erosion, which raises a natural process to unsustainable levels, and has downstream consequences (e.g. economic, environmental and social). Global intensification of agroecosystems is a recognised major cause of soil erosion which, in light of predicted population growth and increased demand for food security, will continue or increase. Transport and redistribution of biota by soil erosion has hitherto been ignored and thus is poorly understood. With the move to sustainable intensification this is a key knowledge gap that needs to be addressed. Here we highlight the erosion-energy and effective-erosion-depth continuum in soils, differentiating between different forms of soil erosion, and argue that nematodes are an appropriate model taxa to investigate impacts of erosion on soil biota across scales. We review the different known mechanisms of soil erosion that impact on soil biota in general, and nematodes in particular, and highlight the few detailed studies, primarily from tropical regions, that have considered soil biota. Based on the limited literature and using nematodes as a model organism we outline future research priorities to initially address the important interrelationships between soil erosion processes and soil biota.
\end{abstract}

\section{Introduction}

Soil productivity is threatened by transport and redistribution of biota by erosion and downstream sediment transport (Powlson et al., 2011). Land use changes enhance mobility of biota (Chapin et al., 2000) over multiple scales, and egress of organisms from ecosystems may decrease system functionality (Díaz et al., 2006; Brussaard et al., 2007). Soil erosion redistributes organic and inorganic materials across the landscape (Dungait et al., 2013); driven by climate, topography, land management and wider anthropogenic impacts (Collins and Owens, 2006; Helming et al., 2006; Powlson et al., 2011). Erosion processes create both degraded eroded and enriched depositional environments. The indirect consequence of these erosional environments may adversely impact soil and soil biota through a decrease in habitat availability, depleted soil structure, increased susceptibility to further erosion and decreased concentrations of organic matter and nutrients in the remaining soil (Joschko et al., 1998). Lal et al. (2007) estimated that $45 \%$ of arable land is degraded. A component of degradation is moving into more erosion-vulnerable areas as good agricultural land is eroded (Pimentel, 2006). With growing intensification of food production systems the security of soil as a provisioning resource, and the supporting services it provides, is uncertain (Banwart, 2011, Garnett et al., 2013). Moreover, future climate changes may increase uncertainty and vulnerability of production systems, and may lead to increased incidence of extreme weather events (IPCC, 2007). There has been a tendency in the literature to overlook if and how soil can tolerate greater demands for increased agricultural yields creating a 
risk that potential vulnerabilities are ignored and thus mismanaged (Banwart, 2011).

Pankhurst (1997) distinguishes between soil quality and soil health, the former a measure of the capacity of soil to meet plant and ecosystem requirements, and the latter more broadly describing the condition of the soil ecosystem and its functionality. Through their discrete roles in the soil food web, biota promote soil quality by maintaining soil health, and in turn maintain productivity, for example in the form of agricultural outputs (Pimentel and Kounang, 1998; Hunt and Wall, 2002; Lavelle et al., 2006; Coleman, 2008). In agroecosystems, soil quality is essential for ensuring food productivity (Moebius-Clune et al., 2011) and can be characterised by chemical, physical and biological parameters (Chen et al., 2010). Soil productivity is threatened by the loss of important ecosystem components, like soil biota, by accelerated erosion and downstream sediment transport. Where soil biota are threatened, so too are the functions they provide in terms of supporting and regulating services (Pimentel, 2006). There is limited research quantifying transport of soil biota by erosive processes and to our knowledge very few studies that have characterised mechanisms responsible for the movement of biota. It is therefore essential to improve our understanding of the impacts of erosion on soil biota to further our knowledge of potential threats to soil.

Here we relate soil physical processes to biological impacts of erosion in temperate agroecosystems focussing on nematodes as a model group (Gupta and Yeates, 1997; Bongers and Ferris, 1999) for assessing water-induced soil erosion effects from plot to catchment scale.

Whilst certain meso- and macro-biota have a unique role in mitigating erosion through direct soil physical restructuring, neither of these functional groups presents an appropriate model taxa for assessing biota redistribution by erosion. The energy exerted by rain splash erosion, for example, would be insufficient to redistribute macro-biota. However microbiota, such as nematodes, are affected by the whole spectrum of soil erosion processes that have different energy potential for eroding soil to different depths - the erosion-energy and effective-erosion-depth continuum. The spectrum of potential consequences of this continuum on soil biota is described in Fig. 1. Moreover, some taxa (e.g. earthworms) can actively avoid unfavourable soil conditions (e.g. saturation) due to their motility (Roots, 1956), and this may skew experimental results. Furthermore some studies have reported the role of macro-biota in bringing more erodible soil material such as earthworm casts to the soil surface (Hindell et al., 1994, 1997a, b; Barré et al., 2009). Thus notwithstanding the positive role of meso- and macro-biota for mitigating erosion (Ehlers, 1975; Roth and Joschko, 1991; Langmaack et al., 2001), we believe that micro-biota, and in particular nematodes, are a more appropriate functional taxa for assessing redistribution of soil biota along the erosion-energy and effective-erosion-depth continuum.
In this review we highlight issues of egress of soil biota, as a consequence of water-induced soil erosion, at a range of scales. We postulate that nematodes are an appropriate model organism for such work. We review the current understanding of soil erosion in agroecosystems, knowledge on soil biota and erosion in general, and review the current understanding of erosion impacts on soil nematodes, before outlining key research priorities.

\subsection{Soil nematodes: a model for assessing erosion impacts to biota}

Unravelling complexities of the soil food web using a multitrophic approach is challenging (Ferris et al., 2001; Koch et al., 2011; Santorufo et al., 2012). The diversity and distribution of biota in soils, coupled with the heterogeneity of the soil matrix (Nielsen et al., 2010), require that appropriate biota be selected when seeking to answer questions about ecosystem impacts (Barrios, 2007).

Soil nematodes range from $40 \mu \mathrm{m}$ to $5 \mathrm{~mm}$ long and live on thin water films $(1-5 \mu \mathrm{m})$ surrounding soil particles and move through soil pores of $25-100 \mu \mathrm{m}$ diameter (Neher, 2010). Nematodes serve important roles in the soil food web, are ubiquitous, and all of the $>20000$ described species (Hugot et al., 2001) can be sampled and extracted with relative ease (Bongers and Ferris, 1999; Ritz and Trudgill, 1999). Their high diversity, abundance and trophic heterogeneity can provide insight into the condition of a food web and can aid understanding of ecosystem health and quality (Bongers, 1990). Morphological characteristics of nematodes can be translated into trophic (i.e. functional) groups (Yeates et al., 1993) and the relative abundances of these groups in an assemblage can infer the state of an ecosystem (Zhao and Neher, 2013). Not only are nematodes key players in decomposition and nutrient cycling (Freckman, 1988; DuPont et al., 2009) they are an established indicator taxa of changes in biological and physico-chemical properties of soils due to their sensitivity to disturbance (for example, Gupta and Yeates, 1997; Boag et al., 1998; Porazinska et al. 1999; Neher, 2001; Wall et al., 2002; Yeates, 2003; Landesman et al., 2011; Rajan et al., 2011; Donn et al., 2012; and Griffiths et al., 2012) and thus are a good choice as a model organism for assessing impacts of soil erosion on biota. This contrasts with the potential trophic (functional) plasticity in other soil taxa such as earthworms (Neilson et al., 2000). Furthermore, the application of novel molecular techniques necessary to process the large number of samples to provide robust data sets to address this knowledge gap is well advanced for nematodes (Chen et al., 2010; Donn et al., 2011, 2012; Griffiths et al., 2012) compared to other soil microfauna such as mites, collembola or enchytraeids.

Griffiths et al. (2002) demonstrated that nematode communities respond to changes in the soil environment and that a number of factors are involved, including previous land use, soil structure, soil water regime and species. Griffiths et 


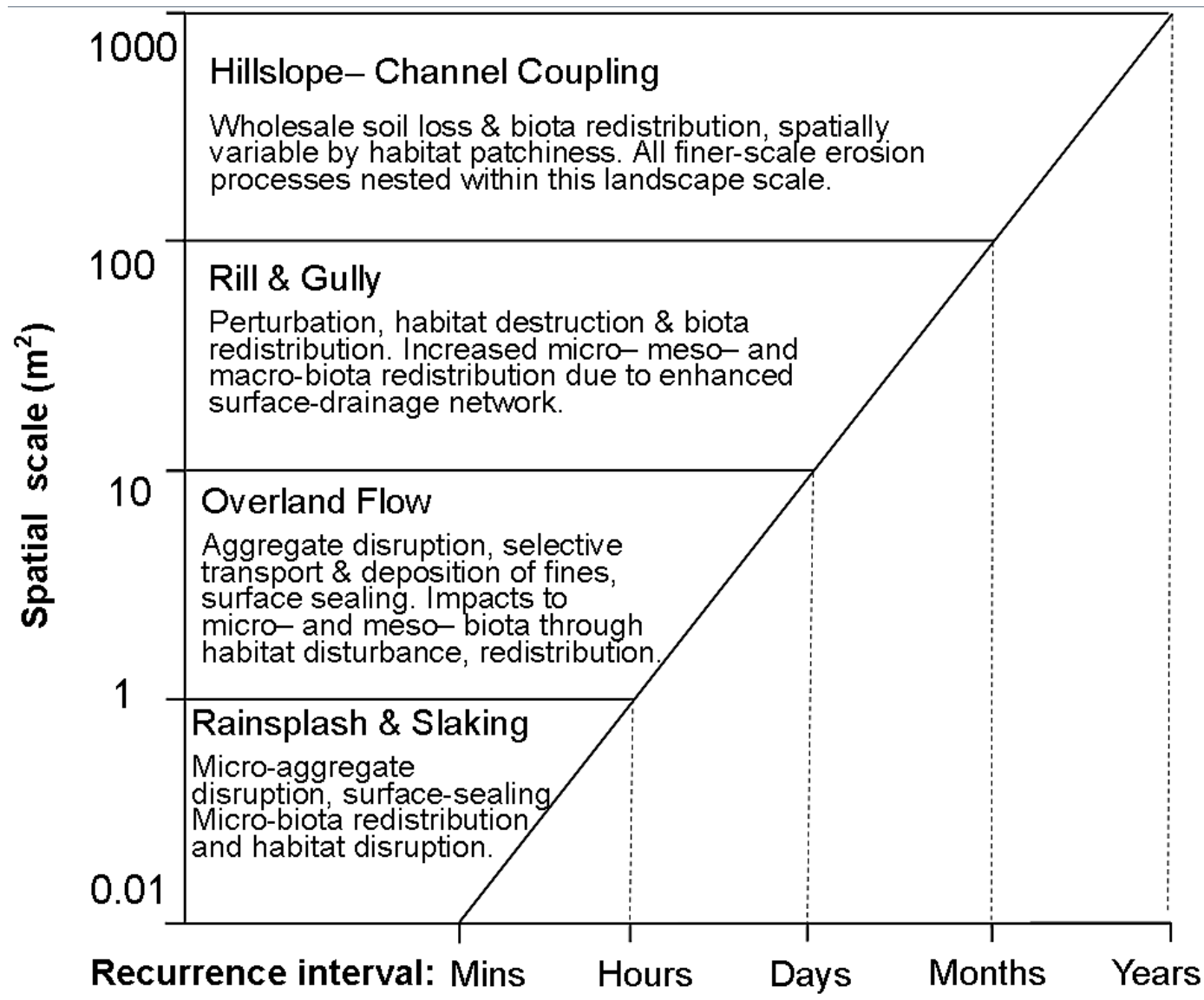

Fig. 1. Conceptual schematic of the nested spatial scales of soil ecosystem function and associated water-induced erosion processes with recurrence interval at which they occur.

al. (2003) further demonstrated that soil properties have an effect on nematode community structure, alongside biological factors, like microbial (food source) and faunal (predators) communities. Nematodes can be used as a model to understand more complex soil ecosystem components (Ritz and Trudgill, 1999) and therefore can be used to investigate the impact of erosion on soil biota.

\section{Soil erosion and sediment budgets}

Soil erosion (the detachment and transport of soil particles and aggregates and associated biota within the soil matrix) involves a series of processes from slopes into channel networks (natural and man-made channels that drain water from land), for which a mass balance, or sediment budget, can be calculated at various scales from plot to catchment (Walling, 1983; Walling and Collins, 2008). By quantifying sediment sources (e.g. hillslopes susceptible to sheet, rill and gully erosion), sinks (e.g. footslopes) and outputs (catchment sediment efflux), an understanding of sediment delivery dynamics can be achieved (Ferguson, 1981; Walling et al., 2001). While gross upland erosion rates may be substantial, net ef- flux of sediment from the catchment system may only be a fraction of that mobilised, with the majority remaining in storage (Phillips, 1991; Trimble and Crosson, 2000). Therefore the consequence for soil biota at the hillslope scale may be one of redistribution as well as loss.

\subsection{Soil erosion by water}

Arable agroecosystems are particularly vulnerable to water erosion, compared with natural grasslands or forest systems. Soil is highly perturbed during conventional cultivation, enhancing loss of organic matter through oxidation and removal during harvest, which can reduce aggregate stability and increase erosion (Dungait et al., 2013). Furthermore arable soils can be left bare and thus vulnerable to erosion following planting until crop cover is established (Davidson and Harrison, 1995).

Rain splash and slaking initiate the erosion process, occurring frequently but contributing minimally to erosion rates, relative to other processes. Energy from raindrops impact the soil surface and compact and break-down aggregates dispersing soil particles. With increased wetting, slaking and dispersion act to release clays and fine silt particles, resulting 
in surface sealing (Warrington et al., 2009), decreasing infiltration and water retention rates. Overland flow occurs either when precipitation exceeds infiltration capacity (infiltration excess overland flow), or when soil pore spaces are full as a result of groundwater flow or interflow (saturation excess overland flow) (Nash et al., 2002). The onset of overland flow depends on antecedent soil water, hydraulic conductivity of soil, and precipitation rate and volume (Emmett, 1978). Initiation of overland flow is typically associated with ponding and sheet flow, developing into complex patterns, influenced by micro-topography and local obstacles. Hydrological flow is typically laminar and selective detachment, entrainment, transport and downslope deposition of fine soil particles occurs. Rills can form as a result of convergence of overland flow, or occasionally by sapping mechanisms (flow of groundwater out of banks on hillslopes), into concentrated micro-channels (dimensions 2-250 mm wide and deep). Confined flow causes scour of rill beds, often accompanied by collapse of steep side-walls that generates sediment of non-specific particle size for transport. Typically rill networks develop by headcut retreat upslope, resulting in stepped-longitudinal profiles (Bryan, 1987). These channels form an efficient transport network for runoff and sediment. Though less widespread across hillslopes, rills erode soil at greater rates than rain splash or sheet flow (Brunton and Bryan, 2000). Gullies can develop through multiple mechanisms (Bull and Kirby, 1997) and are less common than rills, but where locally formed can erode soil at greater rates than rills (Poesen et al., 2003). Gully dimensions are highly variable, but are typically $0.5-30 \mathrm{~m}$ deep and again particle size of eroded sediment is non-selective (Bull and Kirkby, 1997). Soil can also be lost in agroecosystems through mass movements, in the form of rotational and transitional landslides. Such features are usually localised and tend to be associated with the steepest ground $\left(>20^{\circ}\right)$ with relatively little vegetation cover and with significant variations in water table height (Ruhe, 1975; Beguería, 2006; Turkelboom et al., 2008). Although localised, landslides can result in massive and non-selective soil losses downslope.

The susceptibility of soil to erosion, its erodibility, is determined by physical, chemical and biological properties, which include soil texture, amount and nature of organic matter present, water content, land cover and the energy of the eroding force (Mamedov et al., 2000; Verheijen et al., 2009).

The processes involved in water erosion have specific magnitude-frequency relations which determine erosion rates. DEFRA (2006) estimated a typical range of soil-erosion rates by water for England and Wales of 0.1$15 \mathrm{tha}^{-1} \mathrm{yr}^{-1}$. We hypothesise that these erosion rates have a direct effect on the redistribution of soil biota, which until now have remained largely under-investigated, the relationship between magnitude and frequency of different erosive processes are presented in Fig. 2.

\subsection{Soil erosion by wind}

Wind erosion is caused by the combined effect of high wind velocity, loose surface-soil particles and insufficient soilsurface protection (Verheijen et al., 2009). Through surface creep, saltation and suspension, soil particles can be eroded and in England and Wales rates have been estimated at $0.1-2.0 \mathrm{tha}^{-1} \mathrm{yr}^{-1}$ (DEFRA, 2006). Erosion of soil and organic particles by wind can occur when wind speeds exceed $3 \mathrm{~m} \mathrm{~s}^{-1}$ (Carroll and Viglierchio, 1981). In Europe, where wind erosion poses less risk than water erosion, impacts can be localised but extreme and an estimated area of 3 million ha of the north-western European lowlands are at high potential risk, as well as parts of the Mediterranean (Riksen et al., 2003; Verheijen et al., 2009). There is potential for soil biota to be transported by the same erosive mechanisms, for example, Carroll and Viglierchio (1981) measured nematode larvae and egg transport by wind of up to $40 \mathrm{~km}$ from origin, with $5 \mathrm{~km}$ common with dry tillage and optimal weather conditions. Similar processes have been observed in polar (Nkem et al., 2006) and tropical (Baujard and Martiny, 1994) environments. This subsequent loss may exacerbate soil susceptibility to wind erosion, since it has been demonstrated that biota are important in aggregating soil (Tisdall et al., 2012).

\subsection{Soil erosion due to tillage}

Mechanised agriculture increases erosion above background levels, decreasing on-farm productivity and increasing problems associated with diffuse-pollution to downstream channel networks (Verstraeten and Poesen, 1999). An underrecognised dimension of this is the potential for a simultaneous loss of soil biota, which may also be physically redistributed and subject to comparable downstream delivery processes.

Tillage is recognised as one of the major agents of soil erosion (Powlson et al., 2011) and rates can exceed those of natural processes, particularly on slopes (Govers et al., 1994; DEFRA, 2006). As land is cultivated a two-phase erosion process occurs where ploughing breaks aggregates, conditioning them to be displaced (translocated). Compaction as a result of loading from agricultural machinery alters soil properties, which inhibits infiltration and decreases throughflow, promoting increased surface runoff and susceptibility to water and wind-borne soil loss (Addiscott and Thomas, 2000; Bailey et al., 2013). Greatest soil loss from tillage occurs on slope crests and shoulders where slopes are steepest, and deposition occurs in concave breaks in slope (Van Oost et al., 2006). Increased depth and frequency of tillage, ploughing downslope and ploughing on steeper slopes increase the susceptibility of soil to tillage erosion, and accumulations of translocated soil will be most susceptible to subsequent erosion by wind and water (Van Oost et al., 2006; Dlugoß et al., 2012). Translocation distance of soil as a direct result of 


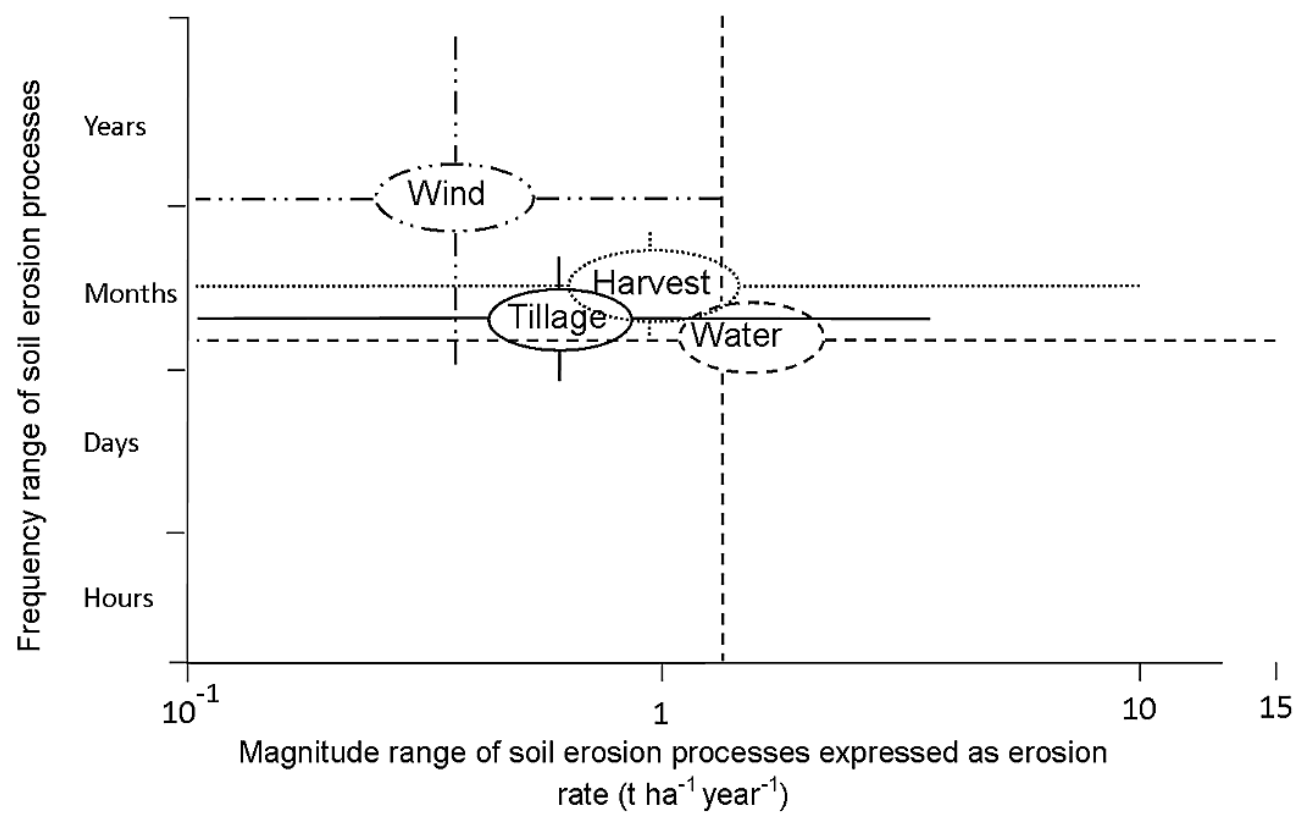

Fig. 2. Conceptual diagram of the frequency range and magnitude range (expressed as rate of erosion: $\mathrm{tha}^{-1} \mathrm{yr}^{-1}$ ) of different soil erosion processes that occur on arable agroecosystem soils. (Magnitude of erosion process $\left(\mathrm{tha}^{-1} \mathrm{yr}^{-1}\right)$ : wind $=0.1-2 ;$ tillage $=0.1-5 ;$ harvest $=0.1-$ 10; water =0.1-15.) (After Ruysschaert et al., 2004; DEFRA, 2006; Verheijen et al., 2009; Van Oost et al., 2009.)

tillage has been recorded to be as much as $10 \mathrm{~m}$ (Van Muysen et al., 2006) and estimates of gross tillage erosion in Europe are quantified at $3.3 \mathrm{tha}^{-1} \mathrm{yr}^{-1}$ (Van Oost et al., 2009). During harvests soil can also be eroded when adhering to farm machinery, and can be "co-extracted" with crops, particularly root crops. Rates of co-extraction in England and Wales have been estimated at $0.1-5.0 \mathrm{tha}^{-1} \mathrm{yr}^{-1}$ (Ruysschaert et al., 2004; DEFRA, 2006; Verheijen et al., 2009).

\subsection{Scales of erosion and the sediment budget}

Figure 2 highlights the link between different mechanisms of erosion that have specific magnitude-frequency relationships that determine erosion rates, which in turn determine sediment fluxes, we hypothesise that similar relationships exist for soil biota. For example, rain-splash erosion is low magnitude, involving distances of $\mathrm{mm}^{2}$ to $\mathrm{cm}^{2}$ (Rickson, 2006) and occurs at high frequency across hillslopes. In contrast, rills occur less frequently, but the magnitude of sediment transport is greater. Only a fraction of eroded sediment from hillslopes reaches the channel network (e.g. $<10 \%$ of eroded sediment; Walling, 1983) due to the dominance of features like overland flow and rill networks (low magnitude). Thus water erosion from hillslopes involves a process of in-field deposition and intermediate storage (e.g. $50 \%$ of total erosion) (Ferguson, 1981). Transport and redistribution of sediment and biota to depositional zones like foot slopes, field margins and buffer strips may thus occur. Therefore within-field redistribution may have significant consequences for environments of net erosion and deposition in terms of biota transport and subsequent soil ecosystem service delivery. Moreover the active movement of biota in response to changes in their environment, for example earthworms have been reported to move upwards in the soil profile due to increased soil water by rainfall (Roots, 1956), which may increase the susceptibility of organisms to transport by erosion.

\section{Linking soil erosion with the soil ecosystem}

The importance of soil to ecosystem services is established (MA, 2005). Biota are fundamental to the delivery of both goods and underpinning services through roles they serve in soil food webs (Barrios, 2007; Ritz et al., 2009). Key roles include organic matter decomposition; nutrient cycling and storage; carbon sequestration; regulating parasites, and creating and maintaining soil aggregation, critical processes for the sustainable management of agroecosystems (Hindell et al., 1997a, b; Neilson et al., 2000; Ferris et al., 2001; Lavelle, 2002; Lavelle et al., 2006; Barrios, 2007). The consequences of soil erosion on biota in terms of ecosystem service provision have hitherto been overlooked.

Biodiversity is central to ecosystem functioning, and soil subjected to stress may display decreased diversity compared with unstressed systems (Brussaard et al., 2007). Ecosystem perturbation, for example by erosion, is unlikely to be restricted to a single trophic level but would cascade through the food web at a range of scales (Pimentel and Kounang, 
1998; Raffaelli et al., 2002), impacting biodiversity and potentially leading to a loss of ecosystem function.

Erosion estimates in Europe range from 3.3 to $17 \mathrm{tha}^{-1} \mathrm{yr}^{-1}$ (Pimentel, 1995; Van Oost et al., 2009), and the range of tolerable erosion rates (rates less than or equal to soil formation rates) have been estimated from 0.3 to $1.4 \mathrm{tha}^{-1} \mathrm{yr}^{-1}$ (Verheijen et al., 2009). Therefore estimated erosion rates in Europe can be at least an order of magnitude greater than rates of soil formation. Soil erosion decreases productivity through loss of water, soil organic matter, nutrients, soil depth and decreased abundance and diversity of soil biota (Atlavinyte, 1964, 1965; Pimentel and Kounang, 1998). In order to follow the assertion by Verheijen et al. (2009) that the definition of "tolerable soil erosion" should include loss or impact to soil function, we must first investigate how erosion impacts biota and the ecosystem services they deliver.

Ecological processes contributing to ecosystem services vary across time and space, from micrometres for microbial processes to hundreds of metres and beyond for soils and landscapes (Lavelle et al., 2004). Similarly erosive processes (Fig. 2) vary spatially and temporally (Verstraeten et al., 2002); thus so will the impacts of erosion on ecosystems and the services they provide. Decreased soil depth, water storage and infiltration capacity, and concentrations of nutrients and soil organic matter are key impacts of erosion that damage the soil ecosystem (Pimentel and Kounang, 1998), impacts of erosion on biota requires further investigation.

Recent estimates suggest that a quarter of all faunal species live exclusively in soil and soil litter (Decaëns et al., 2006). This includes micro-biota (e.g. bacteria, fungi, protozoa and nematodes), meso-biota (e.g. collembola, mites and enchytraeids) and macro-biota (e.g. ants, beetles and earthworms) (Giller et al., 1997).

Lavelle et al. (2006) identified five scales of soil biotic function: (1) microbial bio-films (micro-biota); (2) microfood webs (micro- and meso-biota); (3) functional domains of ecosystem engineers (macro-biota); (4) mosaics of functional domains where groups of macro-biota that affect the soil differently are nested together (macro-biota); (5) landscapes (all biotas). Beare et al. (1995) described five spheres at which biodiversity influences soil structure and function, the detritusphere - decaying plant and animal matter, the drilosphere - zone of earthworm influence, the porosphere - solid particles and air and water filled voids, the aggregatusphere - organic and mineral particle aggregates, and the rhizosphere - zone of primary plant root influence. Combining these definitions with the erosion mechanisms described here (Fig. 1) clearly identifies erosion as a potentially significant dispersal mechanism that operates over scales ranging from individual soil aggregates and micro-habitats to catchment and indeed the landscape scale as in Fig. 1.

Soil micro-aggregates comprised of mineral and organic matter are $<250 \mu \mathrm{m}$ in diameter (Tisdall and Oades, 1982). Micro-biota are likely to colonise and inhabit voids within micro-aggregates from the time of aggregate formation until it is disturbed by mechanical breakdown e.g. associated with tillage or water erosion (Hattori and Hattori, 1993).

Aggregates are greater than $250 \mu \mathrm{m}$ (Tisdall and Oades, 1982), and micro- and meso-biota may dwell within individual aggregates or in the water-filled voids between them, the porosphere. Rain splash erosion may have considerable impact on the structure of surface soils where aggregates are disrupted, broken apart and primary particles displaced. Soil structural changes alter the habitat of biota by clogging pores, as well as physical displacement of biota in the direction of transport. Fine soil particles are selectively entrained by overland flow erosion, and this may also be a transport mechanism for biota similar in size and mass to fine soil particles (Cadet and Albergel, 1999).

Macro-biota occupy the pedosphere, the functional domain of ecosystem engineers (Lavelle et al., 2006). They have a motility mechanism that enables movement through soil and this gives them advantage over meso- and microbiota in responding to unfavourable environmental conditions, e.g. tillage perturbation or physical redistribution by erosion, because they are able to move towards preferable environmental conditions (Roots, 1956).

Rain splash and slaking may only be significant erosive processes for micro- or meso-biota that live on or near the soil surface, but the drilosphere may be impacted as worm burrows become clogged and blocked by fine particles. Moving along the erosion-energy and effective-erosion-depth continuum (rain splash, rills and gullies) typically means less frequent but higher magnitude events that result in soil being lost to greater depths. This has consequences for wholesale transport of the contained biota, with micro- and mesobiota transported in association with the soil, and macrobiota potentially escaping the destruction of the habitat. The impact of erosion at high magnitude, e.g. as a consequence of rill and gully erosion, result in greater stresses translating into loss of habitable space (Pimentel and Kounang, 1998), and indeed loss of habitat, e.g. the detritusphere. Conversely however, whilst negative effects may occur at eroding sites (e.g. hill crests and shoulders), soil depth at depositional sites may increase, and thus potentially improve soil habitat. The nested relationship between the erosion-energy and effectiveerosion-depth continuum, spheres of soil function and soil biota are presented as in Fig. 1 .

\subsection{Soil erosion: transport and passive dispersal of biota}

Dispersal of biota plays a key role in the evolution of populations and species (Gibbs et al., 2010), and drives the spatial and temporal distribution of genotypes (Ronce, 2007). Dispersal can be by movement of organisms (active) or through transport by natural and anthropogenic processes (passive) (Eijsackers, 2011). A body of literature has been dedicated to understanding active dispersal and its role in the evolution of population dynamics, community structure and spatial 
heterogeneity (Bowler and Benton, 2011) that influence patterns of ecosystem services (Ettema and Wardle, 2002).

Wind dispersal has been investigated as a dispersal mechanism for plant parasitic nematodes (PPNs) (Carroll and Viglierchio, 1981; Andrade and Asmus, 1997; de Rooij-van der Goes et al, 1997; Wharton, 2004; Nkem et al., 2006; de la Peña et al., 2011). Dry conditions are necessary and typical transport distances of $5 \mathrm{~km}$ have been reported, as well as extremes of $40 \mathrm{~km}$ (Carroll and Viglierchio, 1981). Nematode ability to enter a state of anhydrobiosis (a dry state where metabolism is reduced to undetectable levels to survive desiccation) has been reported as an adaptation strategy to enable passive dispersal (Carroll and Viglierchio, 1981; Nkem et al., 2006). However, whilst wind transport may be capitalised upon as a dispersal strategy in some habitats, in others, it can cause mortality. In a study of wind blow outs in sand dunes, de Rooij-van der Goes et al. (1997) reported that scour forces caused by saltation of sand particles killed nematodes and as fine particles were set into suspension, nematodes were effectively sieved out by the wind.

Water is a mechanism for passive dispersal of soil biota (Freckman and Baldwin, 1990; Dighton et al., 1997; Terhivuo, 1988; Terhivuo and Saura, 2006; Eijsackers, 2011). Moreover, the role of soil loss through erosion, tillage, harvesting and other agricultural activities is also potentially important in passive dispersal. Boag (1985) demonstrated that virus vector nematodes are passively dispersed at small scales (e.g. plot and field) when soil adheres to farm vehicles and machinery. Rainfall has been identified as a passive dispersal mechanism of PPNs from plot to catchment scale (Freckman and Baldwin, 1990; Hugo and Malan, 2010). Terhivuo (1988) reported that the wide spatial distribution of earthworm (Lumbricidae) species in Finland can in part be attributed to passive dispersal during flooding due to their presence close to the soil surface. Terhivuo and Saura (2006) reported that the earthworm (Eiseniella tetraedra) capitalises on passive dispersal, where eggs are washed into flowing water and over large distances in streams and rivers.

\subsection{Understanding biological consequences of erosion}

It is necessary to consider how soil ecosystems and the services they provide are impacted by redistribution of biota by erosion. Debate remains in the literature regarding the role and importance of the contribution of individual species to ecosystem function (Barrios, 2007), but a combination of the processes of net loss of biota along with physical restructuring of habitats as a consequence of erosion may be damaging. The ecological redundancy hypothesis (Walker, 1992) argues that losing one species would not necessarily lead to loss of ecosystem services, provided key functions were fulfilled by remaining biota. However where there is increasing dependence on species that compensate for losses, resilience of the ecosystem is compromised (Naeem, 1998). We postulate that transport of biota by erosion is likely to affect the whole soil ecosystem, with different species vulnerable to different erosion processes along the erosion-energy and effectiveerosion-depth continuum (Fig. 1). Even with redundancy in the function provided by individual species, potential effects of cumulative erosion over larger timescales (e.g. years to decades) may impact compensating species as well as the physical habitat. In this context the rivet-popping hypothesis (Ehrlich and Ehrlich, 1981) seems more fitting, where the exponential loss of species causes loss of system productivity, leading to eventual system collapse. In the context of agroecosystems a loss of ecosystem function through transport of biota is likely to be offset by increased management including, for example, the use of chemical fertilisers to maintain yields, creating a less sustainable situation.

Therefore the impacts of erosion on soil biota are twofold with (a) physical erosion, transport and redistribution of soil biota, and (b) modification of habitats through erosioninduced restructuring. Erosion can passively disperse soil biota, impacting ecosystem services that underpin productive soils (Pimentel, 1995; Pimentel and Kounang 1998). Over the timescale of years to decades the spatial patterns of erosion and their cumulative consequences to ecosystem structure and function may emerge, and these patterns in turn impact ecosystem services. Furthermore the process of erosion, characterised by the "jerky conveyor belt" (Ferguson, 1981), changes the physical (e.g. soil texture, structure and hydrology) and chemical (e.g. nutrients and soil organic matter) environment, and degrades top and upslope erosional environments enriching downslope depositional environments, modifying the habitat available to soil organisms.

\section{Redistribution of soil nematodes by erosion}

There are limited data of erosion effects on nematode transport, particularly in temperate agroecosystems and related studies identified here are from tropical regions. Cadet and Albergel (1999) reported nematode transport in runoff in the Sudano-Sahelian region of Senegal, which experiences intense erosion during the wet season, and likened nematode size and mass to that of soil particles. The authors noted that half of PPNs transported during the study were transported during the first five rainfall events, at the same time that half of the total runoff was observed, as well as three quarters of total eroded sediment. This study highlighted the potential for redistributed PPNs to adversely impact on crop productivity. Planchon et al. (2000) quantified the relative importance of rain splash and surface wash erosion processes on nematode redistribution on erosion plots in Senegal. This demonstrated that rain splash was responsible for detachment of nematodes from soil as an important precursor to entrainment by surface runoff, which was the key downslope transport mechanism.

Field-plot rainfall simulations showed that nematode entrainment occurred at discharges of $25 \%$ of that necessary 
for loss of soil particles, that drought-adaptation strategies influenced abundance, and less PPNs than other nematodes were found in runoff assemblages (Cadet et al., 2002). Furthermore an important paradox was suggested, PPN redistribution into uninfested areas may be damaging, but the introduction of other nematodes may be beneficial. Villenave et al. (2003) observed selective transport of bacterivorous and omnivorous nematodes in the same experiment. This selectivity was explained by these trophic groups' habitat being in the uppermost soil layers, where the greatest erosion occurred.

Chabrier and Quénéhervé (2008) divided a steep fallow field into plots to test the importance of leaching in translocation of Radopholus similis, a PPN, within a soil profile. They reported that only $20 \%$ of PPNs from inocula added to surfaces of soil plots were leached to depths greater than $10 \mathrm{~cm}$ and thus runoff water was a dominant dispersal mechanism at field scale. The factors identified as controlling loss rates included rainfall intensity, soil water content and transport-path lengths e.g. from PPN-erosion source to field boundaries or the channel network.

Whilst using drainage ditches to isolate crops from potential PPN infestation has been proposed, their use may also create effective pathways for nematodes to reach other environments (Chabrier and Quénéhervé, 2008). Waliullah (1984) reported higher PPN abundances in irrigation canals within the upper Ganges during the rainy season, suggesting that field runoff is an important transport mechanism. Similar results were found in Kashmiri canals (Waliullah, 1989) with higher PPN abundances associated with areas of highest runoff and upland soil erosion. In contrast, comparatively lower PPN abundances were reported in irrigation canals of southern Italy (Roccuzzo and Cianco, 1991), most likely due to the concrete lining of canals that decreased bank erosion and soil-derived PPNs, and the use of flow-regulating dams that allowed PPNs to settle out of the water column (Roccuzzo and Cianco, 1991).

\subsection{Relevant nematode studies from temperate regions}

Evidence from studies in the tropics illustrates the potential role of dispersal of PPN and other nematodes by runoff and associated sediment transport. However, these examples are from tropical regions that have common climatic characteristics involving long dry periods and intense wet seasons with corresponding hydrological regimes. Nematode communities in these regions are adapted to the climate, raising the question of transferability from the tropical studies to temperate agroecosystems.

Early studies into the source of nematodes in irrigation canals in temperate agroecosystems reported rainfall runoff as a key transport mechanism (Faulkner and Bolander, 1966, 1970a, b). Landesman et al. (2011) investigated nematode community response to varying rainfall patterns and showed a positive relationship between increased precipitation and nematode abundance. Certain trophic groups were reported to benefit from resource increases by primary production, and nematodes were found to be highly sensitive to dry conditions. Soils able to retain water will therefore favour nematode survival for longer under drought stress. Conversely, when soil becomes saturated, nematodes may be transported through the soil profile, and thus more vulnerable to transport by erosion, depending on how the soil is saturated.

Nematode densities in drinking water from treatment plants have been positively correlated with precipitation; streamflow and suspended sediment concentrations, with nematodes mobilised from channel-beds and from hillslopes (Tombes et al., 1979; Mott et al., 1981). Similar work undertaken by Mott and Harrison (1983) reported that a substantial proportion of nematodes recorded in streams were from soil habitats, noting a strong correlation between nematode densities and periods of high precipitation, and from snowmelt water.

\section{Research priorities for understanding soil erosion and biota redistribution}

Redistribution of soil biota by erosion may be detrimental to soil ecosystem services through loss of important components of the food web (for example nematodes), alongside a suite of soil chemical and physical impacts and should be addressed as a research priority. Agriculture is a major source of soil erosion, and in the US alone the annual cost of erosion has been estimated at USD 37.6 billion (Uri, 2000), but this figure does not account for the loss of ecosystem services resulting from impacts to soil biota. There exists a need to value changes in ecosystem services resulting from soil erosion.

Further work is necessary to understand the biological impacts of erosion by land use activities (e.g. agriculture) in temperate regions and, in particular, water-induced erosion. As argued earlier, we believe nematodes are a suitable model organism to address some of the most pressing research priorities as outlined below.

\subsection{Mechanisms involved in nematode redistribution by erosion}

The physical erosion mechanisms involved in detaching, transporting and depositing nematodes should be characterised and quantified. Most previous studies (see Sect. 4) do not distinguish between sediment-free clear water runoff phases and more complex sediment-water mixes associated with erosion processes. In order to gain a full understanding of biotic redistribution processes this aspect of nematode redistribution should be addressed as a research priority. This should also take into account the spatial and temporal scales of erosion processes (Figs. 1, 2). Moreover, the influence of environmental factors (e.g. precipitation intensity 
and duration, antecedent soil water, nematode transport-path lengths) and nematode sources highlighted in tropical environments (Walilullah, 1984; Roccuzzo and Cianco, 1991; Chabrier and Quénéhervé, 2008) should be considered.

\subsection{Selectivity of nematode redistribution by erosion}

The diversity of nematode morphology (for example, body length, width, biomass) may influence susceptibility of different functional groups to transport by erosive processes. Thus special attention must be afforded to selectivity of transport by erosion, related to depth distribution of nematodes, which is influenced by access to food resources (e.g. PPNs in the rhizosphere; Villenave et al., 2003).

\subsection{Consequences of erosion-induced physical and chemical soil restructuring to nematodes}

Erosion restructures the soil physical' and chemical environment, both through depletion of erosion-susceptible areas, and by enrichment, or depletion, in depositional areas (for example Joschko et al., 1998). Therefore these effects on soil nematodes and other soil biota should be investigated for potential indirect consequences of erosion.

\subsection{Scaling from plot through field to landscape}

By characterising mechanisms involved in nematode redistribution across the erosion-energy and effective-erosion-depth continuum we can contribute to a better understanding of biota redistribution at greater scales, e.g. catchment, thus enabling an opportunity to fully integrate hydrological and sediment-transport processes at the catchment scale. Using nematodes as a model in these studies provides a foundation for understanding the inter-relationships that occur across the erosion-energy and effective-erosion-depth continuum that can subsequently be applied to other taxa.

\section{Supplementary material related to this article is available online at http://www.biogeosciences.net/10/ 7133/2013/bg-10-7133-2013-supplement.pdf.}

Acknowledgements. The authors wish to thank Kenneth Loades and two anonymous reviewers for their helpful comments; The Centre for Environmental Change and Human Resilience, University of Dundee and The James Hutton Institute for funding the research project. The James Hutton Institute receives financial support from the Scottish Government, Rural and Environment Science and Analytical Services Division.

Edited by: R. Conant

\section{References}

Addiscott, T. M. and Thomas, D.: Tillage, mineralization and leaching: phosphate, Soil Till. Res., 53, 255-273, 2000.

Andrade, P. J. and Asmus, G. L.: The spread of soybean cyst nematode (Heterodera glycines) by wind during soil preparation, Nematol. Bras., 21, 98-100, 1997.

Atlavinyte, O.: Distribution of earthworms (Lumbricidae) and larvae of insects in the eroded soil under cultivated crops, Pedobiologia, 4, 245-250, 1964.

Atlavinyte, O.: The effect of erosion on the population of earthworms (Lumbricidae) in the soils under different crops, Pedobiologia, 5, 178-188, 1965.

Bailey, A., Deasy, C., Quinton, J., Silgram, M., Jackson, B., and Stevens, C.: Determining the cost of in-field mitigation options to reduce sediment and phosphorus loss, Land Use Policy, 30, 234-242, 2013.

Banwart, S.: Save our soils, Nature, 474, 151-152, 2011

Barré, P., McKenzie, B. M., and Hallett, P. D.: Earthworms bring compacted and loose soil to a similar mechanical state, Soil Biol. Biochem., 41, 656-658, 2009.

Barrios, E.: Soil biota, ecosystem services and land productivity, Ecol. Econ., 64, 269-285, 2007.

Baujard, P. and Martiny, B.: Transport of nematodes by wind in the peanut cropping area of Senegal, West Africa, Fund. Appl. Nematol., 17, 543-550, 1994.

Beare, M. H., Coleman, D. C., Crossley, D. A., Hendrix, P. F., and Odum, E. P.: A hierarchical approach to evaluating the significance of soil biodiversity to biogeochemical cycling, Plant Soil, 170, 5-22, 1995.

Beguería, S.: Changes in landcover and shallow landslide activity: a case study in the Spanish Pyrenees, Geomorphology, 74, 196206, 2006.

Boag, B.: The localised spread of virus-vector nematodes adhering to farm machinery, Nematologica, 31, 234-235, 1985.

Boag, B., Hebden, P. M., Neilson, R., and Rodger, S. J.: Observations on the effect of different management regimes of set aside land on nematode community structure, Appl. Soil Ecol., 9, 339343, 1998.

Bongers, T.: The maturity index- an ecological measure of environmental disturbance based on nematode species composition, Oecologia, 83, 14-19, 1990.

Bongers, T. and Ferris, H.: Nematode community structure as a bioindicator in environmental monitoring, Trends Ecol. Evol., 14, 224-228, 1999.

Bowler, D. E. and Benton, T. G.: Testing the interaction between environmental variation and dispersal strategy on population dynamics using a soil mite experimental system, Oecologia, 166, 111-119, 2011

Brunton, D. A. and Bryan, R. B.: Rill network development and sediment budgets, Earth Surf. Proc. Land., 25, 783-800, 2000.

Brussaard, L., de Ruiter, P. C. and Brown, G. G.: Soil biodiversity for agricultural sustainability, Agr. Ecosyst. Environ., 121, 233244, 2007.

Bryan, R. B.: Process and significance of rill development, Catena Supp., 8, 1-16, 1987.

Bull, L. J. and Kirkby, M. J.: Gully processes and modelling, Prog. Phys. Geog., 21, 354-374, 1997. 
Cadet, P. and Albergel, J.: Passive transport of phytoparasitic nematodes by runoff water in the Sudano-Sahelian climatic area. J. Hydrol., 214, 91-102, 1999.

Cadet, P., Planchon, O., Esteves, M., and Lapetite, J. M.: Experimental study of the selective transport of nematodes by runoff water in the Sudano-Sahelian area, Appl. Soil Ecol., 19, 223236, 2002.

Carroll, J. J. and Viglierchio, D. R.: On the transport of nematodes by the wind. J. Nematol., 13, 476-482, 1981.

Chabrier, C. and Quénéhervé, P.: Preventing nematodes from spreading: A case study with Radopholus similis (Cobb) Thorne in a banana field, Crop Prot., 27, 1237-1243, 2008.

Chapin, F. S., Zavaleta, E. S., Eviner, V. T., Naylor, R. L., Vitousek, P. M., Reynolds, H. L., Hooper, D. U., Lavorel, S., Sala, O. E., Hobbie, S. E., Mack, M. C. and Díaz, S.: Consequences of changing biodiversity, Nature, 405, 234-242, 2000.

Chen, X. Y., Daniell, T. J., Neilson, R., O'Flaherty, V., and Griffiths, B. S.: A comparison of molecular methods for monitoring soil nematodes and their use as biological indicators, Eur. J. Soil Biol., 46, 319-324, 2010.

Coleman, D. C.: From peds to paradoxes: linkages between soil biota and their influences on ecological processes, Soil Biol. Biochem., 40, 271-289, 2008.

Collins, A. J. and Owens, P. N.: Introduction to soil erosion and sediment redistribution in river catchments: Measurement, modelling and management in the 21st Century, in: Soil Erosion and Sediment Redistribution in River Catchments: Measurement, Modelling and Management, edited by: Collins, A. J. and Owens, P. N., CABI, Wallingford, 3-12, 2006.

Davidson, D. A. and Harrison, D. J.: The nature, causes and implications of water erosion on arable land in Scotland, Soil Use Manage., 11, 63-68, 1995.

Decaëns, T., Jimenez, J. J., Gioia, C., Measey, G. J., and Lavelle, P.: The values of soil animals for conservation biology, Eur. J. Soil Biol., 42, S23-S38, 2006.

DEFRA: Scoping study of lowland soil loss through wind erosion, tillage erosion and soil co-extracted with root vegetables - Final Report SP 08007, 2006.

de la Peña, E., Vandegehuchte, M. L., Bonte, D., and Moens, M.: Nematodes surfing the waves: long-distance dispersal of soilborne microfauna via sea swept horizons, Oikos, 120, 16491656, 2011.

de Rooij-van der Goes, P. C. E. M., van Dijk, C., van der Putten, W. H., and Jungerius, P. D.: Effects of sand movement by wind on nematodes and soil-borne fungi in coastal fore dunes, J. Coast. Conserv., 3, 133-142, 1997.

Díaz, S., Fargione, J., Chapin, F. S., and Tilman, D.: Biodiversity loss threatens human well-being, PLoS Biol., 4, 1300-1305, 2006.

Dighton, J., Jones, H. E., Robinson, C. H., and Beckett, J.: The role of abiotic factors, cultivation practices and soil fauna in the dispersal of genetically modified microorganisms in soils, Appl. Soil Ecol., 5, 109-131, 1997.

Dlugoß, V., Fiener, P., Van Oost, K., and Schneider, K.: Model based analysis of lateral and vertical soil carbon fluxes induced by soil redistribution processes in a small agricultural catchment, Earth Surf. Proc. Land., 37, 193-208, 2012.
Donn, S., Neilson, R., Griffiths, B. S., and Daniell, T. D.: Greater coverage of the Phylum Nematoda in SSU rDNA studies, Biol. Fert. Soils, 47, 333-339, 2011.

Donn, S., Neilson, R., Griffiths, B. S., and Daniell, T. D.: A novel molecular approach for rapid assessment of soil nematode assemblages - variation, validation and potential applications, Methods Ecol. Evol, 3, 12-23, 2012.

Dungait, J. A. J., Ghee, C., Rowan, J. S., McKenzie, B. M., Hawes, C., Dixon, E. R., Paterson, E., and Hopkins, D. W.: Microbial responses to the erosional redistribution of soil organic carbon in arable fields, Soil Biol. Biochem., 60, 195-201, 2013.

DuPont, S. T., Ferris, H., and van Horn, M.: Effects of cover crop quality and quantity on nematode-based soil food webs and nutrient cycling, Appl. Soil Ecol., 41, 157-167, 2009.

Ehlers, W.: Observations on earthworm channels and infiltration on tilled and untilled Loess soil, Soil Sci., 119, 242-249, 1975.

Ehrlich, P. R. and Ehrlich, A.: Extinction: the causes and consequences of the disappearance of species, Random House, New York, 1981.

Eijsackers, H.: Earthworms as colonizers of natural and cultivated soil environments, Appl. Soil Ecol., 50, 1-13, 2011.

Emmett, W. W.: Overland flow, in: Hillslope Hydrology, edited by: Kirkby, M. J., John Wiley \& Sons, Chichester, 145-176, 1978.

Ettema, C. H. and Wardle, D. A.: Spatial soil ecology, Trends Ecol. Evol., 17, 177-183, 2002.

Faulkner, L. R. and Bolander, W. J.: Occurrence of large nematode populations in irrigation canals of south central Washington, Nematologica, 12, 591-600, 1966.

Faulkner, L. R. and Bolander, W. J.: Acquisition and distribution of nematodes in irrigation waterways of Columbia-basin in eastern Washington, J. Nematol., 2, 362-367, 1970a.

Faulkner, L. R. and Bolander, W. J.: Agriculturally polluted irrigation water as a source of plant-parasitic nematode infestation, J. Nematol., 2, 368-374, 1970b.

Ferguson, R. I.: Channel forms and channel changes, in: British Rivers, edited by: Lewin, J., George Allen and Unwin, London, 90-120, 1981.

Ferris, H., Bongers, T., and de Goede, R. G. M.: A framework for soil food web diagnostics: extension of the nematode faunal analysis concept, Appl. Soil Ecol., 18, 13-29, 2001.

Freckman, D. W.: Bacterivorous nematodes and organic-matter decomposition, Agr. Ecosyst. Environ., 24, 195-217, 1988.

Freckman, D. W. and Baldwin, J. G.: Nematoda, in: Soil Biology Guide, edited by: Dindal, D. L., John Wiley \& Sons, New York, 155-200, 1990.

Garnett, T., Appleby, M. C., Balmford, A., Bateman, I. J., Benton, T. G., Bloomer, P., Burlingame, B., Dawkins, M., Dolan., L., Fraser., D., Herrero, M., Hoffmann, I., Smith, P., Thornton, P. K., Toulmin, C., Vermeulen, S. J., and Godfray, H. C. J.: Sustainable intensification in agriculture: premises and policies, Science, 341, 33-34, 2013.

Gibbs, M., Saastamoinen, M., Coulon, A., and Stevens, V. M.: Organisms on the move: ecology and evolution of dispersal, Biol. Lett., 6, 146-148, doi:10.1098/rsbl.2009.0820, 2010.

Giller, K. E., Beare, M. H., Lavelle, P., Izac, A. M. N., and Swift, M. J.: Agricultural intensification, soil biodiversity and agroecosystem function, Appl. Soil Ecol., 6, 3-16, 1997. 
Govers, G., Vandaele, K., Desmet, P., Poesen, J., and Bunte, K.: The role of tillage in soil redistribution on hillslopes, Eur. J. Soil Sci., 45, 469-478, 1994.

Griffiths, B. S., Bengough, A. G., Neilson, R., and Trudgill, D. L.: The extent to which nematode communities are affected by soil factors - a pot experiment, Nematology, 4, 943-952, 2002.

Griffiths, B. S., Neilson, R., and Bengough, A. G.: Soil factors determined nematode community composition in a two year pot experiment, Nematology, 5, 889-897, 2003.

Griffiths, B. S., Daniell, T. J., Donn, S., and Neilson, R.: Bioindication potential of using molecular characterisation of the nematode community: Response to soil tillage, Eur. J. Soil Biol., 49, 92-97, 2012.

Gupta, V. V. S. R., and Yeates, G. W.: Soil microfauna as bioindicators of soil health, in: Biological Indicators of Soil Health, edited by: Pankhurst, C. and Doube, B. M., CABI, Wallingford, 201234, 1997

Hattori, R. and Hattori, T.: Soil aggregates as microcosms of bacteria-protozoa biota, Geoderma, 50, 493-501, 1993.

Helming, K. J., Luis Rubio, J., and Boardman, J.: Soil erosion across Europe: research approaches and perspectives, Catena, 68, 71-72, 2006.

Hindell, R. P., McKenzie, B. M., Tisdall, J. M., and Silvapulle, M. J.: Relationships between casts of geophagous earthworms (Lumbricidae, Oligochaeta) and soil water potential II Clay dispersion from casts, Biol. Fert. Soils, 18, 127-131, 1994.

Hindell, R. P., McKenzie, B. M., and Tisdall, J. M.: Destabilization of soil during the production of earthworm (Lumbricidae) and artificial casts, Biol. Fert. Soils, 24, 153-163, 1997a.

Hindell, R. P., McKenzie, B. M., and Tisdall, J. M.: Influence of drying and ageing on the stabilization of earthworm (Lumbricidae) casts, Biol. Fert. Soils, 25, 27-35, 1997b.

Hugo, H. J. and Malan, A. P.: Occurrence and control of plantparasitic nematodes in irrigation water - a review, S. Afr. J. Enol. Vitic., 31, 169-180, 2010.

Hugot, J. P., Baujard, P., and Morand, S.: Biodiversity in helminths and nematodes as a field of study: an overview, Nematology, 3, 199-208, 2001.

Hunt, H. W. and Wall, D. H.: Modelling the effects of loss of soil biodiversity on ecosystem function, Glob. Change Biol., 8, 3350, 2002.

IPCC: Climate Change 2007 - the physical science basis Working group 1 contribution to the 4th assessment report of the Intergovernmental Panel of Climate Change, Cambridge University Press, 2007.

Joschko, M., Rogasik, H., Dannowski, M., Hierold, W., and Heisler, C.: A catena in northeast Brandenburg (Bölkendorf): Soil biota, root growth and soil structure, Arch. Acker. Pfl. Boden. 154, 101-105, 1998.

Koch, A. J., Drever, M. C., and Martin, K.: The efficacy of common species as indicators: avian responses to disturbance in British Columbia, Canada, Biodivers. Conserv., 20, 3555-3575, 2011.

Lal, R., Follett, R. F., Stewart, B. A., and Kimble, J. M.: Soil carbon sequestration to mitigate climate change and advance food security, Soil Sci., 172, 943-956, 2007.

Landesman, W. J., Treonis, A. M., and Dighton, J.: Effects of a one-year rainfall manipulation on soil nematode abundances and community composition, Pedobiologia, 54, 87-91, 2011.
Langmaack, M., Schrader, S., and Helming, K.: Effect of mesofaunal activity on the rehabilitation of sealed soil surfaces, Appl. Soil. Ecol. 16, 121-130, 2001.

Lavelle, P.: Functional domains in soils, Ecol. Res., 17, 441-450, 2002.

Lavelle, P., Bignell, D. E., Austen, M. C., Brown, V. K., BehanPelletier, V., Garey, J. R., Giller, P. S., Hawkins, S. J., Brown, G. G., St John, M., Hunt, H. W., and Paul, E. A.: Connecting soil and sediment biodiversity: The role of scale and Implications for Management, in: Sustaining Biodiversity and Ecosystem Services in Soils and Sediments, edited by: Wall, D. H., Island Press, Washington, 193-224, 2004.

Lavelle, P., Decaëns, T., Aubert, M., Barot, S., Blouin, M., Bureau, F., Margerie, P., Mora, P., and Rossi, J. P.: Soil invertebrates and ecosystem services, Euro. J. Soil Biol., 42, S3-S15, 2006.

MA: Millennium Ecosystem Assessment: ecosystems and human well-being: current states and trends: findings of the condition and trends working group, edited by: Hassan, R., Scholes, R. and Ash, N., London, Island Press, 2005.

Mamedov, A. I., Shainberg, I., and Levy, G. J.: Rainfall energy effects on runoff and interrill erosion in effluent irrigated soils, Soil Sci., 165, 535-544, 2000.

Moebius-Clune, B. N., van Es, H. M., Idowu, O. J., Schinelbeck, R. R., Kimetu, J. M., Ngoze, S., Lehmann, J., and Kinyangi, J. M.: Long-term soil quality degradation along a cultivation chronosequence in western Kenya, Agr. Ecosys. Environ., 141, 86-99, 2011.

Mott, J. B. and Harrison, A. D.: Nematodes from river drift and surface drinking water supplies in southern Ontario, Hydrobiologia, 102, 27-38, 1983.

Mott, J. B., Mulamoottil, G., and Harrison, A. D.: A 13-month survey of nematodes at three water treatment plants in southern Ontario, Canada, Water Res., 15, 729-738, 1981.

Naeem, S,: Species redundancy and ecosystem reliability, Conserv. Biol., 12, 39-45, 1998.

Nash, D., Halliwell, D., and Cox, J.: Hydrological mobilization of pollutants at the field/ slope scale, in: Agriculture, hydrology and water quality, edited by: Haygarth, P. M. and Jarvis, S. C., CABI, Oxford, 225-242, 2002.

Neher, D. A.: Role of nematodes in soil health and their use as indicators, J. Nematol., 33, 161-168, 2001.

Neher, D. A.: Ecology of plant and free-living nematodes in natural and agricultural soil, Annu. Rev. Phytopathol., 48, 371-394, 2010.

Neilson, R., Boag, B., and Smith, M.: Earthworm $\delta^{13} \mathrm{C}$ and $\delta^{15} \mathrm{~N}$ analyses suggest that putative functional classifications of earthworms are site-specific and may also indicate habitat diversity, Soil Biol. Biochem., 32, 1053-1061, 2000.

Nielsen, U. N., Osler, G. H. R., Campbell, C. D., Neilson, R., Burslem, D. F. R. P., and van der Wal, R.: The enigma of soil animal species diversity revisited: the role of small-scale heterogeneity, PLOS One, 5, e11567, doi:10.1371/journal.pone.0011567, 2010.

Nkem, J. N., Wall, D. H., Virginia, R. A., Barrett, J. E., Broos, E. J., Porazinska, D. L., and Adams, B. J.: Wind dispersal of soil invertebrates in the McMurdo Dry Valleys, Antarctica, Polar Biol., 29, 346-352, 2006. 
Pankhurst, C. E.: Biodiversity of soil organisms as an indicator of soil health. In: Biological indicators of soil health, CABI, Wallingford, 297-317, 1997.

Phillips, J. D.: Fluvial sediment budgets in the North Carolina Piedmont, Geomorphology, 4, 231-241, 1991.

Pimentel, D.: Environmental and economic costs of soil erosion and conservation benefits, Science, 267, 1117-1122, 1995.

Pimentel, D.: Soil erosion: A food and environmental threat, Environ. Dev. Sustain., 8, 119-137, 2006.

Pimentel, D. and Kounang, N.: Ecology of soil erosion in ecosystems. Ecosystems, 1, 416-426, 1998.

Planchon, O., Cadet, P., Lapetite, J. M., Silvera, N., and Esteves, M.: Relationship between raindrop erosion and runoff erosion under simulated rainfall in the Sudano-Sahel: consequences for the spread of nematodes by runoff, Earth Surf. Proc. Land., 25, 729-741, 2000.

Poesen, J., Nachtergale, G., Verstraeten, C., and Valentin, C.: Gully erosion and evironmental change: importance and research needs, Catena, 50, 91-133, 2003.

Porazinska, D. L., Duncan, L. W., McSorley, R., and Graham, J. H.: Nematode communities as indicators of status and processes of a soil ecosystem influenced by agricultural management practices, Appl. Soil Ecol., 13, 69-86, 1999.

Powlson, D. S., Gregory, P. J., Whalley, W. R., Quinton, J. N., Hopkins, D. W., Whitmore, A. P., Hirsch, P. R., and Goulding, K. W. T.: Soil management in relation to sustainable agriculture and ecosystem services, Food Policy, 36, S72-S87, 2011.

Raffaelli, D., van der Putten, W. H., Persson, L., Wardle, D. A., Petchey, O. L., Koricheva, J., van der Heijden, M., Mikola, J., and Kennedy, T.: Multi-trophic dynamics and ecosystem processes, in: Biodiversity and Ecosystem Functioning: Synthesis and Perspectives, edited by: Loreau, M., Naeem, S., and Inchausti, P., Oxford University Press, 147-154, 2002.

Rajan, R., Khetarpal, K., and Varaprasad, K. S.: Nematodes: important players in biosecurity planning, Biodiversity, 12, 46-48, 2011.

Rickson, R. J.; Management of sediment production and prevention in river catchments: a matter of scale?, in: Soil Erosion and Sediment Redistribution in River Catchments: Measurement, modelling and management, edited by: Owens, P. N. and Collins, A. J., CABI, 228-238, 2006.

Riksen, M., Brouwer, F., and de Graaff, J.: Soil conservation policy measures to control wind erosion in north-western Europe, Catena, 52, 309-326, 2003.

Ritz, K., and Trudgill, D. L.: Utility of nematode community analysis as an integrated measure of the functional state of soils: perspectives and challenges, Plant Soil, 212, 1-11, 1999.

Ritz, K., Black, H. I. J., Campbell, C. D., Harris, J. A., and Wood, C.: Selecting biological indicators for monitoring soils: a framework for balancing scientific and technical opinion to assist policy development, Ecol. Indic., 9, 1212-1221, 2009.

Roccuzzo, G. and Ciancio, A.: Notes on nematodes found in irrigation water in southern Italy, Nematol. medit., 19, 105-108, 1991.

Ronce, O.: How does it feel to be like a rolling stone? Ten questions about dispersal evolution, Annu. Rev. Ecol. Evol. S., 38, 231253, 2007

Roots, B. I.: The water relations of earthworms 2: resistance to desiccation and immersion, and behaviour when submerged and when allowed a choice of environment, J. Exp. Biol., 33, 29-44, 1956.

Roth, C. H. and Joschko, M.: A note on the reduction of runoff from crusted soils by earthworm burrows and artificial channels, J. Plant Nutr. Soil Sc., 154, 101-105, 1991.

Ruhe, R. V.: Geomorphology: Geomorphic processes and surficial geology, Houghton Mifflin Company, Boston, 1975.

Ruysschaert, G., Poesen, J., Verstraeten, G., and Govers, G.: Soil loss due to crop harvesting: significance and determining factors, Prog. Phys. Geog. 28, 467-501, 2004.

Santorufo, L., Van Gestel, C. A. M., Rocco, A., and Maisto, G.: Soil invertebrates as bioindicators of urban soil quality, Environ. Pollut., 161, 57-63, 2012.

Terhivuo, J.: The Finnish Lumbricidae (Oligochaeta) fauna and its formation, Ann. Zool. Fenn., 25, 229-247, 1988.

Terhivuo, J. and Saura, A.: Dispersal and clonal diversity of NorthEuropean parthenogenetic earthworms, Biol. Invasions, 8, 12051218, 2006.

Tisdall, J. M. and Oades, J. M.: Organic matter and water-stable aggregates in soils, J. Soil Sci., 33, 141-163, 1982.

Tisdall, J. M., Nelson, S. E., Wilkinson, K. G., Smith, S. E., and McKenzie, B. M.: Stabilisation of soil against wind erosion by six saprotrophic fungi, Soil Biol. Biochem., 50, 134-141, 2012.

Tombes, A. S., Abernathy, A. R., Welch, D. M., and Lewis, S. A.: Relationship between rainfall and nematode density in drinking water, Water Res., 13, 619-622, 1979.

Trimble, S. W. and Crosson, P.: Land use - US soil erosion rates myth and reality, Science, 289, 248-250, 2000.

Turkelboom, F., Poesen, J., and Trébuil, G.: The multiple land degradation effects caused by land-use intensification in tropical steeplands: a catchment study from northern Thailand, Catena, 75, 102-116, 2008.

Uri, N.: A note on soil erosion and its environmental consequences in the United States, Water Air Soil Poll., 129, 181-197, 2000.

Van Muysen, W., Van Oost, K., and Govers, G.: Soil translocation resulting from multiple passes of tillage under normal field operating conditions, Soil Till. Res., 87, 218-230, 2006.

Van Oost, K., Govers, G., De Alba, S., and Quine, T. A.: Tillage erosion: a review of controlling factors and implications for soil quality, Prog. Phys. Geog., 30, 443-466, 2006.

Van Oost, K., Cerdan, O., and Quine, T. A.: Accelerated sediment fluxes by water and tillage on European agricultural land, Earth Surf. Proc. Land., 34, 1625-1634, 2009.

Verheijen, F. G. A., Jones, R. J. A., Rickson, R. J., and Smith, C. J.: Tolerable versus actual erosion rates in Europe, Earth-Sci. Rev., 94, 23-38, 2009.

Verstraeten, G. and Poesen, J.: The nature of small-scale flooding, muddy floods and retention pond sediment in central Belgium, Geomorphology, 29, 275-292, 1999.

Verstraeten, G., Van Oost, K., Van Rompaey, A., Poesen, J., and Govers, G.: Evaluating and integrated approach to catchment management to reduce soil loss and sediment pollution through modelling, Soil Use Manage., 19, 386-394, 2002.

Villenave, C., Cadet, P., Planchon, O., Esteves, M., and Lapetite, J. M.: Transport of free-living nematodes by runoff water in a Sudano-Sahelian area, Appl. Soil Ecol., 23, 85-91, 2003.

Waliullah, M. I. S.: Nematodes in irrigation water, Nematol. medit., 12, 243-245, 1984. 
Waliullah, M. I. S.: Nematodes in irrigation canals of the Kashmir Valley, India, Nematol. medit., 17, 55-56, 1989.

Walker, B. H.: Biodiversity and ecological redundancy, Conserv. Biol., 6, 18-23, 1992.

Wall, J. W., Skene, K. S., and Neilson, R.: Nematode community and trophic structure along a sand dune succession, Biol. Fert. Soils, 35, 293-301, 2002.

Walling, D. E.: The sediment delivery problem, J. Hydrol., 65, 209237, 1983.

Walling, D. E. and Collins, A. L.: The catchment sediment budget as a management tool, Environ. Sci. Policy, 11, 136-143, 2008.

Walling, D. E., Collins, A. L., Sichingabula, H. M., and Leeks, G. J. L.: Integrated assessment of suspended sediment budgets: a Zambian example, Land Degrad Dev., 12, 387-415, 2001.
Warrington, D. N., Mamedov,, A. I., Bhardwaj, A. K., and Levy, G. J.: Primary particle size distribution of eroded material affected by degree of aggregate slaking and seal development, Euro. J. Soil Sci., 60, 84-93, 2009.

Wharton, D. A.: Survival Strategies. In: Nematode Behaviour, edited by: Gaugler, R. and Bilgrami, A. L., CABI, UK, 2004.

Yeates, G. W.: Nematodes as soil indicators: functional and biodiversity aspects, Biol. Fert. Soils, 37, 199-210, 2003.

Yeates, G. W., Bongers, T., de Goede, R. G. M., Freckman, D. W., and Georgieva, S. S.: Feeding habits in soil nematode families and genera - an outline for soil ecologists, J. Nematol., 25, 315331, 1993.

Zhao, J. and Neher, D. A.: Soil nematode genera that predict specific types of disturbance, Appl. Soil Ecol., 64, 135-141, 2013. 